\title{
Competitive Position of CFS Operations in Voc Port Trust, Thoothukudi
}

\author{
R. Ramamoorthy, Pavithra.J,Velvizhi
}

\begin{abstract}
The research has a done a pilot studies of above mentioned subject and found that totally there are 26 CFS operator located in and around Thoothukudi. Further researcher found that $60 \%$ of the import volume of the containers moved to the import volume of that rest 40\%has taken direct out from the port. The researcher came to know that being only $60 \%$ of port volume is distributed among the CFS there is, heavy competition running around them, to maintain the market share and the brand value. The researcher further found that consignee is a major player in the trade then $\mathrm{CHA}$ and liner for CFS nomination, this induced the researcher to study the above mentioned subject pertaining to the import and export point of view. The methods of research study used by the researcher to observe in customer point of view are survey method, observation method and questionnaire method.
\end{abstract}

Keywords : CFS operator,, questionnaire

\section{INTRODUCTION}

Compartment Freight Station (CFS) is a transitory travel office for fare/import (EXIM) payload. They are available appropriate at the overhauling port. CFS is where holders are stiffed, de-stuffed and collection/isolation of fare/import freight happens. With the developing volume of worldwide exchange, the requirement for quick freedom of products at the port inside the base conceivable time has been picking up significance. [1],[3],[5]

This is all the more so when the ports are confronting clog at their premises. Further, for ideal usage of existing foundation, space, gear, merchandise that are arrived at ports should be cleared straight away with no loss of time. Appropriately the idea of CFS has developed in significance alongside the advancement and development of ports.

CFSs possess a critical spot in the coordinations worth chain. They work as outsider distribution centers, giving productive freight putting away and recovering offices, in this manner diminishing the stock holding cost. Right now stock conveying cost speak to around $8-10 \%$ of the absolute creation cost. They are likewise called inland holder Depots (ICDs) when they are available in the hinterland, away from the serving port. Around the world, CFSs are picking up

Revised Manuscript Received on July 22, 2019.

Mr. R. Ramamoorthy Assistant Professor,Department of MBA,Bharath institute of Higher Education \& Research,Tamilnadu,India ramamoorthy0071@gmail.com

Pavithra.J, Assistant Professor,Department of MBA,Bharath institute of Higher Education \& Research,Tamilnadu,India Email: pavithralect@yahoo.com

Velvizhi Assistant Professor,Department of CSE,Bharath institute of Higher Education \& Research,Tamilnadu,India Email: velvizhisp@ gmail.com noticeable quality with expanding payload traffic among real ports.. Examination of the effectiveness parameters of various sorts of CFSs in THOOTHUKUDI arranged dependent on their proprietorship design. CFS is where holders are full, de-stuffed and collection/isolation of fare/import load occur[7],[9],[11].

\section{OBJECTIVES OF THE STUDY}

\section{a. Primary Objective}

To study on competitive position of the CFS operating in voc port trust Thoothukudi. [8],[ 10],[12]

b. Secondary Objectives

- To analysis various customer's facilities in CFS.

- To study about procedure faced in the CFS trade.

- To study about various parameters of requirements of the importers exporters from the CFS operation.

- To study about the strategy of CFS to find better place among others.

- To give suggestion and recommendation for future study.

\section{RESEARCH DESIGN}

A. Research area:

\section{VOC PORT TRUST,THOOTHUKUDI}

B. Research design

Descriptive research design

\section{Research approach:}

Research design selected for this project is Descriptive

D. Research period:

Three months.

\section{METHOD OF DATA COLLECTION}

A. Data source:

$>$ Primary data

Secondary data 


\section{B. Research instrument:}

Questionnaire consists of open ended, dichotomous, and closed ended. [2 ],[4],[6]

\section{SAMPLING METHOD}

\section{Sample population:}

The population for this research study consists of the residence of Thoothukudi.

\section{Sample size:}

The sample size is taken as 200 .

\section{Sampling Technique:}

The sampling technique used is simple random sampling.

\section{STATISTICAL TOOLS USED}

\section{Statistical tools}

\section{Percentage Analysis.}

\section{LIMITATIONS OF THE STUDY}

- The researcher has considered only physically and operational parameter to describe and analyses the objectives of the above mentioned study.

- The researcher tries find out the competitive CFS operator by considering above slated objectives.

- In this project research the major limitation could be the data is depended on the secondary source that is Available.

- This study should be read if the analyze is then keeping other parameter/variable has constant.

- The research is limited to the CFS located in Thoothukudi and is based upon information from consignee and CFS operator.

- The researcher has considered only Thoothukudi port volume distributor to the CFS operators.

\section{SIGNIFICANCE OF THE STUDY}

The research has a done a pilot studies of above mentioned subject and found that totally there are $26 \mathrm{CFS}$ operator located in and around Thoothukudi. Further researcher found that $60 \%$ of the import volume of the containers moved to the import volume of that rest $40 \%$ has taken direct out from the port. The researcher came to know that being only $60 \%$ of port volume is distributed among the CFS there is, heavy competition running around them, to maintain the market share and the brand value. The researcher further found that consignee is a major player in the trade then CHA and liner for CFS nomination, this induced the researcher to study the above mentioned subject pertaining to the import and export point of view. The methods of research study used by the researcher to observe in customer point of view are survey method, observation method and questionnaire method. [13], [15] ,[ 17]

\section{RESULTS \&DISCUSSION}

All the clearing and sending offices studied are taking care of containerized load and $94 \%$ of them are utilizing the holder cargo station for their shipments. [14],[ 16], [18]
- $99 \%$ of the respondents are taking care of dry holders, different compartments are exceptionally uncommon. $17.5 \%$ are taking care of open top and $15.5 \%$ are utilizing reefer holders. Just $8.5 \%$ of the organizations reviewed handle level rack holders.

- $90.5 \%$ of the offices reviewed utilize the CFS for custom freedom of their load, while $74.5 \%$ use it for stuffing and $71 \%$ use it for de stuffing. $48.5 \%$ use it for holding containerized load and $26 \%$ use it to store loaded compartments.

- Among the different CFS's in the city A.S Shipping and Greenway delivery is the most liked. $47.5 \%$ reacted they incline toward the abovementioned while $42.55 \%$ favor utilizing Toothukudi port trust.

- The principle elements considered while choosing a compartment cargo station are positioned by their inclinations as offices accessible, security courses of action made, custom official posting, motivating forces gave and CFS notoriety

- The extra offices anticipated while utilizing a compartment cargo station are EDI offices, Round the clock administration, Pick up van offices, flask offices and rail siding office in a specific order. [19],[21],[23]

- The significance level related with the different traits of a compartment cargo station are Quality and quickness of administration conveyance, Tariff paces of CFS, Equipment and labor accessible at CFS, area of CFS and zone accessible at CFS in a specific order.

- It is discovered that $92.55 \%$ of the clients change their holder cargo station as indicated by their need and the principle explanations behind changing a CFS are given as awful administration of present CFS, different CFS citing a lesser cost, change in custom official posting at CFS, change in sort of products took care of and increment in their compartment volume in a specific order.

- The mindfulness level of Toothukudi port trust is $100 \%$ and the $82.98 \%$ offices have used the administrations of Toothukudi port trust. [20],[22], [24]

- It has been discovered that $34.5 \%$ organizations anticipate that an expansion of 21 should 30 TEU's in their containerized volume soon.

- The factors that will incite more developments to the CFS are quicker custom leeway, decreased vehicle charges, giving more impetuses, giving all the more free days and quicker PNR conveyance in a specific order.

- It is discovered that $34 \%$ of the organizations are expecting and increment of 21 to 30 TEU's in their containerized volume soon. [25],[27],[29]

- There is no connection between the Number of years in business and the Number of holders dealt with by the $\mathrm{C}$ and F Agencies.

- There is no connection between the Number of years in business and the quantity of compartments moved to the holder cargo station by the $\mathrm{C}$ and $\mathrm{F}$ Agencies.

- The appropriation of Number of holders dealt with is decidedly slanted while the dispersion of Number of compartments moved to the holder cargo station for taking care of is contrarily slanted. [31],[33] 


\section{CONCLUSION}

From this exploration the analyst sees that there is a positive potential for beginning new holder cargo stations in Thoothukudi city. With endeavors being made to change over Thoothukudi into a center point port, it will undoubtedly pull in more compartment traffic later on. Consequently we can say that there is positively enough extension for more holder cargo stations in Thoothukudi. Steady extension is imperative to keep in pace with the creating market. [26],[28],[30] The analyst has proposed a few proposals and suggestions to the organization to address the future difficulties in this market.

\section{REFERENCES}

1) BharthVajan R., Ramachandran S.,Psychographic dimensions of training,2016,International Journal of Pharmacy and Technology,V-8,I-4,P-23727-23729

2) Balakrishnan P., Bharthvajan R.,A study on human resource planning in hospitals in Chennai City,2014,International Journal of Applied Engineering Research,V-9,I-22,P-7503-7507

3) Priyadarsini P., Bharthvajan R.,Role of emotional intelligence training programme in reducing the stress of the nurses,2014,International Journal of Applied Engineering Research,V-9,I-22,P-7411-7421

4) Kerinab Beenu G., Bharthvajan R.,Empirical analysis on the cosmetic buying behavior of young women in South India,2014,International Journal of Applied Engineering Research,V-9,I-22,P-7361-7366

5) Balakrishnan P., Bharthvajan R.,Whistling in the wind,2014,International Journal of Applied Engineering Research,V-9,I-22,P-7586-7593

6) Krishnan B., Peter M.,Health hazards of Indian Bpo employee-an alarming issue,2014,International Journal of Applied Engineering Research,V-9,I-22,P-7336-7341

7) Kerinab Beenu G.H., Peter M.,Role of insurance in economic development,2014,International Journal of Applied Engineering Research,V-9,I-22,P-7532-7539

8) Balakrishnan P., Peter M., Priyadarsini P.,Efficiency of safety measures for wellbeing of employees in manufacturing industry,2014,International Journal of Applied Engineering Research,V-9,I-22,P-7376-7382

9) Anbarasi M., Praveen Kumar S.,Online sales promotions of herbal products and its effectiveness towards tanisha.com,2019,Indian Journal of Public Health Research and Development,V-10,I-1,P-195-200

10) Anbarasi M., Praveen Kumar S.,Various online marketing and promotions strategies to improve the validation towards the organic products in the pharmaceutical sectors,2019,Indian Journal of Public Health Research and Development, V-10,I-1,P-263-269

11) Loganathan R., Praveen Kumar S.,Grievance handling a key factor for solving issues of employees in an organization,2014,International Journal of Applied Engineering Research,V-9,I-22,P-7483-7491

12) Loganathan R., Praveen Kumar S.,Study on preference of private label brands in super and Hypermarkets,2014,International Journal of Applied Engineering Research,V-9,I-22,P-7327-7335

13) Smitha M., Praveen Kumar S.,Understanding stress and its managementamong the nurses in Chennai city,2014,International Journal of Applied Engineering Research,V-9,I-22,P-7560-7565

14) Kerinab Beenu G.H., Praveen Kumar S.,A study on the investment behavior of Chennai investors in mutual fund schemes,2014,International Journal of Applied Engineering Research,V-9,I-22,P-7520-7525

15) Loganathan R., Praveen Kumar S.,Retention strategies key for organizational productivity,2014,International Journal of Applied Engineering Research,V-9,I-22,P-7443-7447

16) Pavithra J., Ganesan M., Brindha G.,State wise analysis of microfinance sector in India,2016,International Journal of Pharmacy and Technology,V-8,I-4,P-23417-23432

17) Pavithra J., Ganesan M.,A comparative study on microfinance in India and abroad,2016,International Journal of Applied Business and Economic Research,V-14,I-8,P-5471-5476
18) Pavithra J., Ganesan M.,A study on awareness and impact of micro-financial schemes,2016,International Journal of Applied Business and Economic Research,V-14,I-8,P-5449-5460

19) Senthilmurugan P., Pavithra J.,Consumer preference towards organised retailing with reference to Big Bazaar,2014,International Journal of Applied Engineering Research,V-9,I-22,P-7469-7475

20) Senthilmurugan P., Pavithra J.,Implication of social media marketing in growing healthcare industry,2014,International Journal of Applied Engineering Research,V-9,I-22,P-7448-7456

21) Loganathan R., Pavithra J.,Consumer perception towards private label brand over other brands in super markets and hypermarkets,2014,International Journal of Applied Engineering Research,V-9,I-22,P-7355-7360

22) Kerinab Beenu G., Pavithra J.,Tradeâ€"off between liquidity and profitability in logistics industry,2014,International Journal of Applied Engineering Research,V-9,I-22,P-7398-7401

23) Kerinab Beenu G., Pavithra J.,A study on the prospective consumerâ€ $€^{\mathrm{TM}_{\mathrm{S}}}$ perception towards utility cars in Chennai city,2014,International Journal of Applied Engineering Research,V-9,I-22,P-7526-7531

24) Pavithra J., Dilli Babu P., Ambuli T.V.,A study on budgetary control at Maruti Service Masters, Chennai,2014,International Journal of Applied Business and Economic Research,V-12,I-2,P-151-161

25) Pavithra J., Dilli Babu P., Ambuli T.V.,A study on customer satisfaction of retro Garments Pvt Ltd, Chennai,2014,International Journal of Applied Business and Economic Research,V-12,I-2,P-381-391

26) Kerinab Beenu G.H., Pavithra J., Senthilmurugan P.,A study on the influence of promotional activities for TATA ARIA among consumers in Chennai,2014,International Journal of Applied Engineering Research,V-9,I-22,P-7572-7578

27) Vijayaragavan S.P.,An investigative expert that's general FBG sensors,International Journal of Mechanical Engineering and Technology,V-8,I-8,PP-1500-1505,Y-2017

28) Vijayaragavan S.P.,Equalization routing protocol for Wi-Fi sensor strategy,International Journal of Mechanical Engineering and Technology,V-8,I-8,PP-1662-1666,Y-2017

29) Karthik B., Kiran Kumar T.V.U., Vijayaragavan P., Bharath Kumaran E.,Design of a digital PLL using 0.35 $\hat{\mathrm{I}}^{1} / 4 \mathrm{~m}$ CMOS technology,Middle East Journal of Scientific Research,V-18,I-12,PP-1803-1806,Y-2013

30) Kanniga E., Selvaramarathnam K., Sundararajan M.,Kandigital bike operating system,Middle - East Journal of Scientific Research, V

31) Jasmin M., Vigneshwaran T., Beulah Hemalatha S.,Design of power aware on chip embedded memory based FSM encoding in FPGA,International Journal of Applied Engineering Research,V-10,I-2,PP-4487-4496,Y-2015

32) Jasmin M.,Optimization techniques for low power VLSI circuits,Middle East Journal of Scientific Research,V-20,I-9,PP-1082-1087,Y-2014

33) Jasmin M., Vigneswaran T.,Fuzzy controller for error control of on - Chip communication,2017 International Conference on Algorithms, Methodology, Models and Applications in Emerging Technologies, ICAMMAET 2017,V-2017-January,I-,PP-1-5,Y-2017

\section{AUTHORS PROFILE}

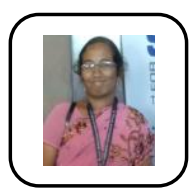

Pavithra.J Assistant Professor,Department of MBA,Bharath institute of Higher Education \& Research,Tamilnadu,India

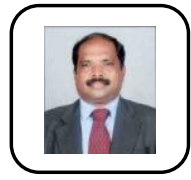

Mr. R. Ramamoorthy, Assistant Professor,Department of MBA,Bharath institute of Higher Education \& Research,Tamilnadu,India.

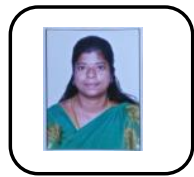

Velvizhi Assistant Professor,Department of CSE,Bharath institute of Higher Education \& Research,Tamilnadu,India 